\title{
Statistical Analysis of Water Quality Parameters of the Drina River (West Serbia), 2004-11
}

\author{
Igor Leščešen ${ }^{1 *}$, Milana Pantelić², Dragan Dolinaj², \\ Vladimir Stojanovićz, Dragan Milošević
}

\begin{abstract}
${ }^{1}$ Department for Geography, Tourism and Hotel Management, Faculty of Science, University of Novi Sad ${ }^{2}$ Climatology and Hydrology Research Centre, Faculty of Science, University of Novi Sad, Trg Dositeja Obradovića 3, 21000 Novi Sad, Serbia
\end{abstract}

Received: 16 April 2014

Accepted: 3 September 2014

\begin{abstract}
The Drina River is the biggest tributary of the Sava River, created by the merger of the Tara and Piva rivers at Šćepan Polje. The Drina represents the border between Serbia and Bosnia and Herzegovina. Water quality index (WQI) is a numeric expression used to evaluate the quality of water bodies and make it more easily understood by managers. In this study, the water quality status and the spatial and temporal trends along the Drina were assessed through the application of seven WQI parameters, to an eight-year public database of environmental data (2004-11). Water quality of the Drina is one of the significant factors taken into consideration in evaluation of sustainability of the development of this region and it is controlled by complex anthropogenic activities and natural factors. Values of $\mathrm{pH}$ grew steadily from $\mathrm{CP} 1$ to $\mathrm{CP} 3$, but on $\mathrm{CP} 4$ values of $\mathrm{pH}$ were lower (8.11) than on two previous control points (CP2 8.14 and CP3 8.16). $\mathrm{O}_{2}$ saturation shows highest values at CP1 $121.3 \%$, while the lowest values were observed at $\mathrm{CP} 3101.8 \% . \mathrm{BOD}_{5}$ at all four $\mathrm{CPs}$ shows that water quality of the Drina can be classified as I class $(<2 \mathrm{mg} / \mathrm{l})$. According to statistical data processing we can state that Drina water quality at all four control points allows for its exploitation.
\end{abstract}

Keywords: Drina, water quality, Serbia, River

\section{Introduction}

Rational and preservation utilization of water resources represents one of the main problems of the $21^{\text {st }}$ century. Water as a resource is a valued quantity, quality, and by location, where the quality is a condition of the water system, expressed through physical-chemical, chemical, and biological indicators. The important aspects taken into consideration when examining the top-priority problems of water quality are economic influence, the influence on human health, influence on the ecosystem, and influence of the geographic area, as well as duration of the influence [1]. Changes in the physico-chemical characteristics of water

*e-mail: igorlescesen@yahoo.com quality are influenced not only by anthropogenic factors, but also by combined interactive natural processes such as hydrological conditions, topography and lithology, climate, precipitation inputs, catchment area, tectonic and edaphic factors, erosion, weathering of crustal materials and bedrock geology, in combination with environmental influence [2]. It should be also taken into account that the Republic of Serbia is striving toward membership within the EU, and reaching good water quality represents an important challenge [3]. The most important legal framework within the European Union (EU), which regulates water policies, is the Water Framework Directive (WFD) [4].

River systems play an important role in the sustainable development of the whole environment, especially when 
running through populated regions [5]. In order to provide the sustainability of ecological balance, the presence and quality of water are very important [6] and there has been more research based on water quality observations [7, 8]. Anthropogenic influences can cause negative consequences in a short period of time as far as water quality is concerned [9], whereas water body pollution represents the result of human activities on one hand, and intensive urbanization development on the other [10]. The organic solid load and the dynamics of its degradation are very good indicators of anthropogenic impact on water [11].

Over the last few decades the rivers and river channels are increasingly becoming receivers for the disposal of wastewater that is the product of the industry and of the local population in urban areas. The discharge of wastewater into surface water has reached alarming levels and is today one of the serious problems of water courses [12, 13]. In many developed countries have been adopted by the government strict legal measures by which all wastewater before discharge must first be treated (scrubbed) to reduce their pollution and then discharged into the watercourse [14]. Despite all the legal regulations, in many rivers pollutants exceed the limits because the catchment area is not able to assimilate all the wastewater that is deposited there $[13,15]$.

Water quality is one of the most important factors that must be taken into account when assessing the sustainability of the development of a region [16]. The rapid development of economy and water quality is severely degraded. Poor water quality and degraded environment will not only hamper sustainable development but may threaten the health of the population [17]. To ensure the sustainability of the ecological balance, the presence and quality of water is important [18]. Because of this, research based on the monitoring of water quality has been getting more intense over the last decade $[7,8,14]$.

\section{Material and Methods}

\section{Sampling Area}

The Drina River is the biggest tributary of the Sava River (Fig. 1). It is created by the confluence of the Tara and Piva rivers at Šćepan Polje $428 \mathrm{~m}$ above sea level. The mouth of the Drina in the Sava is near the town of Bosanska Rača at $78 \mathrm{~m}$ above sea level. The catchment area is $19,570 \mathrm{~km}^{2}$. In Serbia the catchment area is $6,007 \mathrm{~km}^{2}$ the Drina River represents the state border between the Republic of Serbia and the Bosnia and Herzegovina for 220 $\mathrm{km}$. Average altitude of the catchment area is $934 \mathrm{~m}$. Composition of the Tara and Piva rivers is at $432 \mathrm{~m}$ and the confluence is at $75 \mathrm{~m}$. The length of Drina is $346 \mathrm{~km}$ [19]. The biggest and the most important tributary of the Drina is the Lim River (Serbia), which represent the right tributary. Other important tributaries are Sutjeska, Đehotina, Drinjača, and Prača from Bosnia and Herzegovina, and Jadar and Rzav in Serbia. The Drina downriver from the town of Loznica enters the Pannonian plane.

\section{Data and Methods}

The database of the Republic Hydrometeorological Service for 2004-11 [20] was used to present the existing state of water quality of the Drina according to set limit values of quality markers (Official Bulletin of SFRY No. 6/78). The obtained data are analyzed in the SPSS statistical program. Presented results were obtained according to several different statistical analyses applied in similar research: descriptive statistical analysis [21], one-way analysis of variance (ANOVA) [13, 22-25], and t-test analysis for independent samples. The post-hoc Scheffe test was applied for definition of difference significance between certain groups $[14,26]$.

Descriptive statistical analysis was applied for definition of parameter mean values according to profiles and time periods.

One-way analysis of variance is a statistical procedure that ensures difference testing between several arithmetic means. If certain result deviations from total arithmetic means are squared (squared deviations), and these squares are summed ("square sums" in variance analysis), total square sum (SS) is obtained, which can be divided in two square "sub-sums": square sums within the group and square sum between the groups.

However, the definition of SS within and between the groups does not enable us to conclude if variability is greater within or between the groups, since square sum amount depends on the number of results. Therefore, variance is taken as variability measure. Variance value is obtained when each SS values is divided by the corresponding number of freedom degrees. This expression is called middle square (MS).

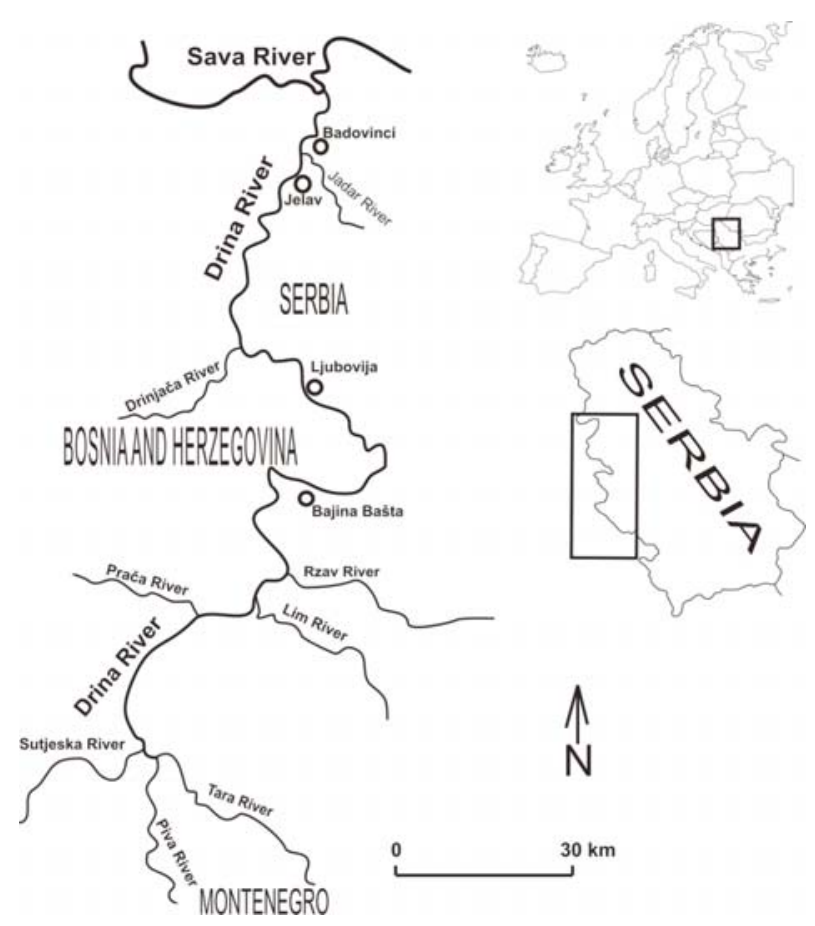

Fig. 1. Geographical location of control points on the Drina River. 
Table 1. Mean values of chemical parameters showing water quality for four CPs at the Drina River and ANOVA results.

\begin{tabular}{|l|c|c|c|c|c|c|}
\hline \multicolumn{1}{|c|}{ Parameters } & $\begin{array}{c}\text { Bajina Bašta } \\
(\mathrm{CP} 1)\end{array}$ & $\begin{array}{c}\text { Ljubovija } \\
(\mathrm{CP} 2)\end{array}$ & $\begin{array}{c}\text { Jelav } \\
(\mathrm{CP} 3)\end{array}$ & $\begin{array}{c}\text { Badovinci } \\
(\mathrm{CP} 4)\end{array}$ & $\mathrm{F}$ & $\mathrm{p}$ \\
\hline $\mathrm{pH}$ & 8.06 & 8.14 & 8.16 & 8.11 & 1.921 & 0.126 \\
\hline Conductivity $(\mu \mathrm{S} / \mathrm{cm})$ & 285.06 & 287.34 & 299.31 & 297.31 & 5.999 & $0.001^{*}$ \\
\hline $\mathrm{O}_{2}$ saturation $(\%)$ & 121.31 & 102.61 & 101.84 & 102.34 & 9.572 & $0.000^{*}$ \\
\hline $\mathrm{BOD}_{5}\left(\mathrm{mgO}_{2} / \mathrm{l}\right)$ & 1.71 & 0.86 & 0.89 & 1.19 & 28.897 & $0.000^{*}$ \\
\hline Suspended solids $(\mathrm{mg} / \mathrm{l})$ & 4.78 & 7.47 & 8.35 & 14.54 & 5.76 & $0.001^{*}$ \\
\hline Total oxidized nitrogen $(\mathrm{mg} / \mathrm{l})$ & 0.53 & 0.54 & 0.50 & 0.56 & 0.461 & 0.710 \\
\hline Amount of coliform bacteria $(\mathrm{n} / \mathrm{l})$ & 2150.7 & 2999.56 & 4338.26 & 2500.00 & 0.933 & 0.429 \\
\hline
\end{tabular}

${ }^{*} \mathrm{p}<0.01 ; \mathrm{p}<0.05 ; \mathrm{F}>3.32$;

Source: Created by the author based on data analysis in SPSS 20.0.

Freedom degrees for SS within groups are calculated when the number of groups is substracted from the general number of results (since there are N-1 freedom degrees in each group). Freedom degrees for SS between groups are calculated when 1 is substracted from the number of groups.

Post-hoc Scheffe test: If F-test proves there are statistically significant differences, it is important to define the groups among which there are statistically significant differences. The results of F-test can only prove significance of difference between the groups with the lowest and highest arithmetic means.

Difference significance between particular groups can be defined according to post-hoc test, i.e. technique for systematic error risk lessening, whereas the error can be caused by a greater number of comparisons between two arithemtic means. Scheffe post-hoc test, as one of the most strict and most often applied tests, was used in this research. Procedure included following steps [27]:

1. After $F$ values in variance analysis were defined, the following formula is applied for each pair of arithemtic means:

$$
F=\frac{\left(M_{a i}-M_{b}\right)^{2}}{M S_{w g}\left(N_{a}+N_{b}\right) \div N_{a} N_{b}}
$$

2. $\mathrm{F}$ value for needed significance level for freedom degrees $((\mathrm{k}-1)$ and $(\mathrm{N}-1))$ is read from $\mathrm{F}$ table.

3. Set $\mathrm{F}$ value is multiplied with $(\mathrm{k}-1)$, and new limit value $\left(F^{\prime}\right)$ is obtained.

4. $\mathrm{F}$ is calculated according to the above-mentioned formula for all pairs of arithmetic means and obtained value is compared with $\mathrm{F}^{\prime}$. If $\mathrm{F}$ is higher than $\mathrm{F}^{\prime}$, that difference can be considered to be statistically significant at the significance level set in step 2 .

The sample fulfills basic conditions for parametre test application, i.e. data used in analysis originating from interval scale and they are normally distributed.

T-test for independent samples is used for comparison of mean values of results and definition of statistical significance of their differences. Independent samples are samples that do not have any correlation after measurement [28].
Risk possibility level of 5\% and 1\% was taken into account in the process of definition of statistical significance of obtained results, whereas the limit is based on freedom degrees interpreted according to t-tables. At examined samples at significance level of $5 \%(\mathrm{p}<0.05)$ or less, $t$ value must be at least 1.96, whereas at significance level of $1 \%$ $(\mathrm{p}<0.01), \mathrm{t}$ must be at least 2.58 [29].

\section{Results and Discussion}

Mean values for seven chemical parameters $(\mathrm{pH}$, conductivity, dissolved $\mathrm{O}_{2}, \mathrm{BOD}_{5}$, suspended solids, and amount of coliform bacteria) for the observed eight-year period (2004-11), as well as the results of ANOVA test for all four Control Points (Bajina Bašta (CP1), Ljubovija (CP2), Jelav (CP3), and Badovinci (CP4)) are presented in Table 1. Their values are presented in Hydrological annual book for 2004, 2005, 2006, 2007, 2008, 2009, 2010, and 2011 of the Republic Hydrometeorological Service of Serbia.

ANOVA was used to define if there is statistically significant correlation between dependent variables (parameters: $\mathrm{pH}$, Conductivity, $\mathrm{O}_{2}$ saturation, $\mathrm{BOD}_{5}$, suspended solids, Total oxidized nitrogen, and amount of coliform bacteria) and independent variable (CP). Post-hoc Scheffe test was applied to define significantly different variables.

The $\mathrm{pH}$ of surface waters is vital to aquatic life. It affects the ability of aquatic organisms to regulate basic life-sustaining processes, primarily the exchange of respiratory gasses and salts with the water in which they live [30]. Statistical analysis of $\mathrm{pH}$ for all four measurement stations don't show significant differences at significance level $\mathrm{p}<0.01(\mathrm{~F}=1.921, \mathrm{p}=0.126)$. The highest values of $\mathrm{pH}$ were measured at CP3 station (8.16), no significant deviations are measured between all four stations. Although it should be noted that values of $\mathrm{pH}$ grew stadily from $\mathrm{CP} 1$ to $\mathrm{CP} 3$, but on $\mathrm{CP} 4$ values of $\mathrm{pH}$ were lower (8.11) than on two previous control points (CP2 8.14 and CP3 8.16), which is the result of fresh water inflow from the Jadar River. The results of post-hoc test confirm that there are no statistically significant differences between the values of $\mathrm{pH}$. 
Table 2. One-way analysis of variance ANOVA per year.

\begin{tabular}{|l|c|c|c|c|c|c|c|c|c|c|}
\hline \multicolumn{1}{|c|}{ Parameters } & 2004 & 2005 & 2006 & 2007 & 2008 & 2009 & 2010 & 2011 & $\mathrm{~F}$ & $\mathrm{p}$ \\
\hline $\mathrm{pH}$ & 7.950 & 8.061 & 8.260 & 8.062 & 8.107 & 8.157 & 8.189 & 8.202 & 5.438 & $0.000^{*}$ \\
\hline Conductivity $(\mu \mathrm{S} / \mathrm{cm})$ & 291.667 & 295.957 & 302.119 & 307.366 & 286.333 & 273.609 & 287.000 & 299.682 & 7.356 & $0.000^{*}$ \\
\hline $\mathrm{O}_{2}$ saturation $(\%)$ & 102.000 & 102.596 & 104.452 & 138.890 & 102.078 & 102.478 & 100.021 & 102.886 & 9.721 & $0.000^{*}$ \\
\hline $\mathrm{BOD}_{5}\left(\mathrm{mgO}_{2} / \mathrm{l}\right)$ & 0.974 & 1.322 & 1.063 & 1.131 & 1.185 & 0.916 & 1.175 & 1.248 & 1.570 & 0.144 \\
\hline Suspended solids $(\mathrm{mg} / \mathrm{l})$ & 6.083 & 6.865 & 12.298 & 7.600 & 8.656 & 7.186 & 18.979 & 3.705 & 4.021 & $0.000^{*}$ \\
\hline $\begin{array}{l}\text { Total oxidized nitrogen } \\
(\mathrm{mg} / \mathrm{l})\end{array}$ & 0.476 & 0.604 & 0.455 & 0.665 & 0.620 & 0.516 & 0.481 & 0.451 & 2.679 & 0.010 \\
\hline $\begin{array}{l}\text { Amount of coliform } \\
\text { bacteria }(\mathrm{n} / \mathrm{l})\end{array}$ & - & 1913.875 & 2056.667 & 1868.500 & 4080.000 & 4587.500 & 2163.636 & 4457.500 & 0.965 & 0.454 \\
\hline
\end{tabular}

${ }^{*} \mathrm{p}<0.01 ; \mathrm{p}<0.05 ; \mathrm{F}>3.32$;

Source: Created by the author based on data analysis in SPSS 20.0.

The one-way analysis of variance (Table 2) confirmed the existence of statistically significant differences for $\mathrm{pH}$ on the level of significance $\mathrm{p}<0.01(\mathrm{~F}=5.438, \mathrm{p}=0.000)$. This difference is visible between 2004 and 2006, 2010, and 2011. The biggest difference is between 2004 and 2006, where mean differences is 0.3095 .

Measured values of conductivity for the research period show significant differences at significance level $\mathrm{p}<0.01$ $(\mathrm{F}=5.999, \mathrm{p}=0.001)$. Highest values were measured at $\mathrm{CP} 1$ station and the lowest at CP3 station. This is confirmed with the post-hoc test, which shows is statistically significant differences between these two stations. According to the Scheffes test, the significant differences were observed between 2005, 2006, 2007, 2011, and 2009. The biggest difference was observed between 2007 and 2009. By applying the one-way analysis of variance (Table 2) it was determined that there are differences between values of conductivity on the level of significance $r<0.01$ ( $F=9.721$, $\mathrm{p}=0.000$ ) between mentioned years.

Oxygen is very important in maintaining the quality of aquatic ecosystems and is essential for the respiration of aquatic organisms [1]. $\mathrm{O}_{2}$ saturation shows highest values at CP1 (121.3\%) while the lowest values were observed at CP3 (101.8\%). Statistical analysis of $\mathrm{O}_{2}$ saturation for all four measurement stations shows significant differences at significance level $\mathrm{p}<0.01(\mathrm{~F}=9.572, \mathrm{p}=0.000)$. For 2007, according to Scheffes test, the significant difference were observed between this year (2007) and every other year. Results of analysis of $\mathrm{O}_{2}$ saturation according to one-way analysis of variance (Table 2) for an eight-year period show significant statistical difference on the level of $p<0.01$ $(\mathrm{F}=9.721, \mathrm{p}=0.000)$. The reason for the lower percentage of oxygen can easily be releasing degrading organic matter, and untreated sewage system into the river, mainly from bigger settlements such as the Bajina Bašta and Ljubovija.

$\mathrm{BOD}_{5}$ is a parameter that indicates the level of organic pollution. The results of $\mathrm{BOD}_{5}$ values (Table 1) are different at all four stations. Statistically significant differences at significance level $\mathrm{p}<0.05(\mathrm{~F}=28.897, \mathrm{p}=0.000)$ are defined according to this parameter. Mean value of $\mathrm{BOD}_{5}$ is regis- tered at CP1 (1.708) and the lowest values are measured at CP2 (0.858). The results of post-hoc tests show statistically significant difference between $\mathrm{BOD}_{5}$ values at all observed profiles, but they also show that these differences are greatest between $\mathrm{CP} 1$, where higher levels of $\mathrm{BOD}_{5}$ are registered, and $\mathrm{CP} 2$, but on all four stations water quality could be described as satisfactory according to this parameter. For $\mathrm{BOD}_{5}$ no significant statistical differences were observed according to Scheffes test. Observed values of $\mathrm{BOD}_{5}$ at all four CPs show that Drina water quality can be classified as class $\mathrm{I}(<2 \mathrm{mg} / \mathrm{l})$. Values of $\mathrm{BOD}_{5}$, total oxidized nitrogen, and amount of coliform bacteria according one-way ANOVA test (Table 2) show no significant statistical differences according to factor analysis of variance during the period from 2004 to 2011.

Suspended solids are closely linked to erosion and nutrient transport (phosphor, especially), metal, industrial waste, and chemicals used in agriculture transport $[1,14]$. The amount of suspended solids grew steadily downstream, reaching highest values on CP4 (14.54 mg/l) (Table 1). This is mostly due to terrain characteristics, as the river flows from mountain terrain that dominates the upstream part of the river, downstream of Loznica, where the Drina flows into the Pannonian plain near the river mouth into the Sava River. The significant statistical difference according to Scheffes test was observed between 2004 and 2010 . Analysis of suspended solids with one-way ANOVA (Table 2) show significant differences on the level of $p<0.01$ $(\mathrm{F}=4.021, \mathrm{p}=0.000$ ) between 2004 and 2010, this difference is due to a higher intensity of erosion as a consequence of higher precipitation in 2010.

Nitrogen materials are of great importance to the quality of the streams, as a nutrient substance may cause undesired occurrence of eutrophication, or overproduction of biomass. After the passage of the growing season for algae, they will become a substrate for microorganisms and passing through the food chain will result in an additional increase in silt in the stream and oxygen consumption. Lowest mean total oxidized nitrogen (TON) values for investigated stations were observed at CP3 $0.502 \mathrm{mg} / \mathrm{l}$ 
Table 3. T-test analysis for certain chemical parameters that show water quality in warmer and colder periods at complete waterflow of the Drina River.

\begin{tabular}{|c|c|c|c|c|c|}
\hline Parameters & $\begin{array}{l}\text { Period } \\
\text { of year }\end{array}$ & M & $\sigma$ & t-test & $\mathrm{p}$ \\
\hline \multirow{2}{*}{$\mathrm{pH}$} & W & 8.168 & 0.367 & \multirow{2}{*}{3.121} & \multirow{2}{*}{$0.002 *$} \\
\hline & $\mathrm{C}$ & 8.070 & 0.179 & & \\
\hline \multirow{2}{*}{$\begin{array}{l}\text { Conductivity } \\
(\mu \mathrm{S} / \mathrm{cm})\end{array}$} & W & 293.484 & 29.415 & \multirow{2}{*}{0.609} & \multirow{2}{*}{0.543} \\
\hline & $\mathrm{C}$ & 291.698 & 25.929 & & \\
\hline \multirow{2}{*}{$\begin{array}{c}\mathrm{O}_{2} \text { saturation } \\
(\%)\end{array}$} & W & 110.566 & 32.322 & \multirow{2}{*}{2.849} & \multirow{2}{*}{$0.005^{*}$} \\
\hline & $\mathrm{C}$ & 102.026 & 24.288 & & \\
\hline \multirow{2}{*}{$\begin{array}{c}\mathrm{BOD}_{5} \\
\left(\mathrm{mgO}_{2} / 1\right)\end{array}$} & W & 1.219 & 0.617 & \multirow{2}{*}{2.289} & \multirow{2}{*}{0.023} \\
\hline & $\mathrm{C}$ & 1.043 & 0.757 & & \\
\hline \multirow{2}{*}{$\begin{array}{l}\text { Suspended } \\
\text { solids (mg/l) }\end{array}$} & W & 7.324 & 15.246 & \multirow{2}{*}{-1.931} & \multirow{2}{*}{0.054} \\
\hline & $\mathrm{C}$ & 10.701 & 17.601 & & \\
\hline $\begin{array}{l}\text { Total oxidised } \\
\text { nitrogen } \\
(\mathrm{mg} / \mathrm{l})\end{array}$ & W & 0.527 & 0.402 & -0.346 & 0.730 \\
\hline
\end{tabular}

${ }^{*} \mathrm{p}<0.01 ; \mathrm{p}<0.05 ; \mathrm{W}$ - warm period; $\mathrm{C}$ - cold period

Source: Created by the author based on data analysis in SPSS 20.0 .

while the highest values were observed at CP4 $0.559 \mathrm{mg} / \mathrm{l}$ (Table 1). Statistical analysis for all four measurement stations did not show significant differences at significance level $\mathrm{p}<0.01(\mathrm{~F}=0.461, \mathrm{p}=0.710)$. The lowest values of TON $(0.502 \mathrm{mg} / \mathrm{l})$ are observed just upstream of the mouth of the Jadar into the Drina. Downstream this shows a great influence of this tributary on water quality parameters of Drina. This influence is also observed in values of other parameters. Table 2 results show that values of TON vary from 2004 to 2007, when the highest value was measured at $0.665 \mathrm{mg} / \mathrm{l}$, from this year until 2011 the constant decrease of TON values is observed with the lowest value measured in 2011 at $0.451 \mathrm{mg} / \mathrm{l}$.

High values of coliform bacteria can indicate certain fecal pollution, which mainly originates from untreated sewage wastewater, which can create difficulties in the survival of aquatic life and apply effects to all water users. In the case of Drina, low mean feces water pollution is registered at all four CPs at the Drina during the whole investigated period (Table 1). Significant differences are not observed $(\mathrm{F}=0.933, \mathrm{p}=0.429)$ between observed profiles. The greatest amount of coliform bacteria is registered at CP3 station and the lowest at CP1 and CP4. Highest values for CP3 is a consequence of the towns of Loznca, Ljubovija, and Bajina Bašta sewage system, which is discharged to some extent directly into the river upstream of $\mathrm{CP} 3$. Lower values at CP4 station are measured because of the many Drina tributaries between these two stations, mainly because of the Jadar, which is the right tributary of the Drina. Water of these tributaries diluted water of the Drina. Post-hoc test does not show statistically significant difference between control points. Although there are no statistically significant differences, our results show that mean difference is highest between CP3 and the other three control points. The couse of this is, as we mentioned above, influence of sewage systems of cities upstream of CP3 and the mouth of the Jadar downstream of CP3.

\section{Chemical Parameter Analysis According to the Period of the Year}

Independent sample T-test was applied in order to compare arithmetic means of two groups - parameter values in warmer and colder periods of the year [14].

The results obtained at all four stations show that particular parameter values are different during warmer and colder periods of the year. According to the results of t-test (Table 3) we can state that these differences are statistically significant for many parameters. During the colder period, from October to April, values of $\mathrm{pH}$ at all stations are statistically significant at significance level $\mathrm{p}<0.01(\mathrm{t}=-3.121$, $\mathrm{p}=0.002$ ). Values of $\mathrm{pH}$ are lower in the colder period, from October to April. During the warmer period, from April to October, values of $\mathrm{O}_{2}$ saturation are higher at all four control points, $\mathrm{p}<0.01(\mathrm{t}=2.849, \mathrm{p}=0.005)$. As far as $\mathrm{BOD}_{5}$ parameters, values are higher during the colder period of the year, which is confirmed with results of t-test at significance level $\mathrm{p}<0.05(\mathrm{t}=2.289, \mathrm{p}=0.023)$.

Values of TON are slightly higher during the colder period. From October to April values of TON at all four CPs are not statistically significant at significance level $\mathrm{p}<0.01(\mathrm{t}=-0.346, \mathrm{p}=0.73)$.

As far as suspended solids and amount of coliform bacteria are concerned, their values are higher in the colder period, during autumn and winter. However, these differences are small and they are not statistically significant, suspended solids $(\mathrm{t}=-1.1931, \mathrm{p}=0.054)$, and the amount of coli form bacteria $(\mathrm{t}=-0.852, \mathrm{p}=0.397)$.

The results of post-hoc test confirm that there are no statistically significant differences between the values of $\mathrm{pH}$ on all four stations. The value of $\mathrm{pH}$ is good for all four CPs during the research period (average 8.12). Measured values of conductivity for the research period of eight years show significant differences, with the biggest diference measured between 2009 and 2007. $\mathrm{O}_{2}$ saturation analysis shows differences between 2007 and every other year in the research period. The results of post-hoc tests for $\mathrm{BOD}_{5}$ shows differences between values at all four control points, but they also show that these differences are greatest between CP1 and CP2. The couse of this is greater pollution of the river upstream and downstream of CP1. The amount of suspended solids grew steadily downstream, reaching highest values on CP4. This is due to erosion along the river basin and geological composition of downriver terrain (Panonnian Basin). Statistical analysis of total oxidized nitrogen for all four measurement stations did not show any significant differences between CPs. Mean feces water pollution is low at all Drina CPs during the whole investigated period because of low inflow of wastewater from settlements and a high water discharge, mostly in upstream parts of the river. 
All values change steadily downstream from CP1 to CP3, after CP3, the Drina River receives many tributaries of which the most important is the Jadar, the right tributary of the Drina. Clean fresh water from these rivers influences water parameters of the Drina in a positive way downstream to CP4 and the mouth of the Drina into the Sava. Season and natural factors such as air temperature do not have significant influence on Drina pollution.

\section{Conclusion}

In this study, water quality status and the spatial and temporal trends along the Drina were assessed through the application of seven WQI parameters, to an eight-year public database of environmental data. Based on the chemical parameters of water quality, it can be seen that all four control points - Bajina Bašta (CP1), Ljubovija (CP2), Jelav (CP3) and Badovinci (CP4) - on the entire course of the Drina are pure and completely suitable for exploitation and utilization of all its functions. The greatest value of the Drina is the possibility of using water for supplying cities and industries with clean water that needs only minimum chemical treatment. This is a rare opportunity in the modern world. Water from the river can be used for irrigation of the surrounding agricultural surfaces as agreed by the inhabitants of the local population from the settlements predominantly in the upriver section, in fertile parts of the Panonnian basin. Tourism is also one of the ways that Drina water can be used, in recent years rafting is getting more and more popular, also the diversity of fish species (15) provides a good basis for fishing. Investments in tourism infrastructure could cause development and economic strengthening of settlements along the Drina. A large drop in river flow along the longitudinal profile is used for producing electrical energy of three hydroelectric power plants (Višegrad, Bajina Bašta, and Zvornik).

One of the greatest ecological problems along the river is illegal dumping on river shore and on its tributary shores. This waste during high water ends up in the Drina and disrupts water quality. Municipal authorities of Bajina Baša, Ljubovija, and Loznica invest a lot in removing and cleaning these dump sites, but every year they reappear. Also, as the Drina is a border between the Republic of Serbia and the Republic of Bosnia and Herzegovina, maintaining water quality should be an international responsibility and intergovernmental plans and strategies should be passed.

\section{References}

1. DALMACIJA B., TUMBAS-IVANČEV I. Water analysis quality control, results interpretation. Faculty of Sciences, Department of Chemistry, Novi Sad, 2004 [In Serbian]

2. DAMO R., ICKA P. Evaluation of Water Quality Index for Drinking Water. Pol. J. Environ. Stud., 22, (4), 1045, 2013.

3. GRABIĆ J., BEZDAN A., BENKA P., SALVAI A. Spreading and transformation of nutrients in the reach of the Becej-Bogojevo Canal, Serbia. Carpathian Journal of Earth and Environmental Sciences, 6, (1), 277, 2011
4. DIRECTIVE 2000/60/EC of the European Parliament and of the Council of 23 October 2000 establishing a framework for Community action in the field of water policy, Official Journal of the European Union - 22.12.2000, L 327, 1-73, 2000.

5. KOWALOWSKI T., ZBYTNIEWSKI R., SZPEJNA J., BUSZEWSKI B. Application of chemometrics in river water classification. Water Research 40, (4), 744, 2006.

6. KARADAVUT I. S., SAYDAM A. C., KALIPCI E., KARADAVUT S., ÖZDEMIR C. A research for water pollution of Melendiz stream in terms of sustainability of ecological balance. Carpathian Journal of Earth and Environmental Sciences, 6, (1), 65, 2011.

7. FERENCZI L., BALOG A. A pesticide survey in soil, water and foodstuffs from central Romania. Carpathian Journal of Earth and Environmental Sciences, 5, (1), 111, 2010.

8. PARVULESCU L., HAMCHEVICI C. The relation between water quality and the distribution of Gammarus balcanicus schäferna 1922 (amphipoda: gammaridae) in the anina mountains. Carpathian Journal of Earth and Environmental Sciences, 5, (2), 161, 2010.

9. YUNIS A. J. M., NAKAGOSHI N. Effects of seasonality on streamflow and water quality of the pinang river in Penang Island, Malaysia. Chinese Geographical Science, 14, (2), 153, 2004.

10. DRAGIĆEVIĆ S., NENADOVIĆ S., JOVANOVIĆ B., MILANOVIĆ M., NOVAKOVIĆ I., PAVIĆ D., LJEŠEVIĆ M. Degradation of Topciderska river water quality (Belgrade). Carpathian Journal of Earth and Environmental Sciences, 5, (2), 177, 2010.

11. GURZAU A. E., POPOVICI E., PINTEA A., POPA O., POP C., DUMITRASCU I. Quality of surface water sources from a central transylvanian area as a possible problem for human security and public health. Carpathian Journal of Earth and Environmental Sciences, 5, (2), 119, 2010.

12. ALVAREZ-VAZQUEZ L. J., MARTINEZ A., VAZQUEZMENDEZ M. E., VILAR M. A. An application of optimal control theory to river pollution remediation. Applied Numerical Mathematics, 59, 845, 2009.

13. PANTELIĆ M. Remediation and protection of Veliki Bački canal as a prerequisite for sustainable use of its development potential, $\mathrm{PhD}$ dissertation, University of Novi Sad, Department of geography, tourism and hotel management, 2012 [In Serbian].

14. PANTELIĆ M., DOLINAJ D., SAVIĆ S., STOJANOVIĆ V., NAĐ I. Statistical Analysis of water quality parameters of Veliki Bački Canal (Vojvodina, Serbia) in period 20002009. Carpathian Journal of Earth and Environmental Sciences 7, (2), 255, 2012.

15. ALVAREZ-VAZQEZ L. J., MARTINEZ A., VAZQUEZMENDEZ M.E., VILAR M.A. Flow regulation for water quality restoration in a river section: Modeling and control. Journal of Computational and Applied Mathematics, 234, (4), 1267, 2010.

16. CORDOBA E. B., MARTINEZ A. C., FERRER E. V. Water quality indicators: Comparison of a probabilistic index and a general quality index. The case of the Confederación Hidrográfica del Júcar (Spain). Ecological Indicators, 10, (5), 1049, 2010.

17. HUANG F., WANG X., LOU L., ZHOU Z., WU J. Spatial variation and source apportionment of water pollution in Qiantang River (China) using statistical techniques. Water Res., 44, (5), 1562, 2010.

18. KARADVUT I.S., SAYDAM A. C., KALIPCI E., KARADVUT S., ÖZDEMIR C. A research for water pollu- 
tion of Melendiz stream in terms of sustainability of ecological balance. Carpathian Journal of Earth and Environmental Sciences, 6, (1), 65, 2011.

19. GAVRILOVIĆ Lj., DUKIĆ D. Rivers of Serbia, Institute for Textbooks, Belgrade, 2002 [In Serbian].

20. REPUBLIC HYDROMETEOROLOGICAL SERVICE OF SERBIA (RHMS) (2004-2011). Annual Report - Water quality. Belgrade: Republic Hydrometeorological Service of Serbia.

21. MAGUIRE I., KLOBUČAR G. Size structure, maturity size, growth and condition index of stone crayfish (Austropotamobius torrentium) in North-West Croatia. Knowledge and Management of Aquatic Ecosystems, 401, 12, 2011.

22. XIAOLONG W., JINGYI H., LIGANG X., QI Z. Spatial and seasonal variations of the contamination within water body of the Grand Canal, China. Environmental Pollution, 158, (5), 1513, 2010.

23. PARVULESCU L., PACIOGLU O., HAMCHEVICI C. The assessment of the habitat and water quality requirements of the stone crayfish (Austropotamobius torrentium) and noble crayfish (Astacus astacus) species in the rivers from the Anina Mountains (SW Romania). Knowledge and Management of Aquatic Ecosystems, 401, (03), 2011.
24. PAILLISSON J.-M., SOUDIEUX A., DAMIEN J.-P. Capture efficiency and size selectivity of sampling gears targeting red-swamp crayfish in several freshwater habitats. Knowledge and Management of Aquatic Ecosystems, 401, (06), 2011.

25. NTAKIRUTIMANA T., DU G., GUO J., GAO X., HUANG L. Pollution and potential ecological risk assessment of heavy metals in a lake. Pol. J. Environ. Stud., 22, (4), 1129, 2013.

26. BANHA F., ANASTACIO P. M. Interactions between invasive crayfish and native river shrimp. Knowledge and Management of Aquatic Ecosystems, 401, 17, 2011.

27. PETZ B. Basic Statistical Methods for Non-mathematicians.Liber, Zagreb, 1981 [In Croatian]

28. TURJANČANIN V., ČEKRLIJA Đ. Basic Statistical methods and techniques in SPSS - Application of SPSS in human sciences. Centar za kulturni i socijalni popravak, Banjaluka, 151, 2006 [In Bosnian].

29. STOJKOVIĆ M. Basics of medical statistics. High medical school, Cuprija, 353, 2003 [In Serbian].

30. GONG D., GAO X., NTAKIRUTIMANA T., GUO J., LI K. Water Quality Status along the Liangtan River and Control Planning Alternatives for Pollution Reduction. Pol. J. Environ. Stud., 22, (4), 1061, 2013. 
